\title{
Identifikasi Pseudomonas aeruginosa dan Uji Sensitivitas terhadap Antibiotik dari Sampel Pus Infeksi Luka Operasi di RSUD Dr. Moewardi
}

\author{
Identification of Pseudomonas aeruginosa and Sensitivity Test Toward Antibiotic from Surgical \\ Wound Infection's Pus Sample in Dr. Moewardi General Hospital \\ Aulia Wahyu Sulviana ${ }^{1}$, Nony Puspawati' ${ }^{2}$ dan Rizal Maarif Rukmana ${ }^{2 *}$ \\ ${ }^{1}$ Mahasiswa Program DIV Analis Kesehatan, Fakultas Ilmu Kesehatan, Universitas Setia Budi, Surakarta. \\ ${ }^{2}$ DIV Analis Kesehatan, Fakultas Ilmu Kesehatan, Universitas Setia Budi Surakarta. \\ *Corresponding author: rizal.nerazuri@gmail.com
}

\begin{abstract}
ABSTRAK
Infeksi luka operasi merupakan bagian dari infeksi nosokomial. Salah satu bakteri penyebab tertinggi infeksi luka operasi adalah Pseudomonas aeruginosa. Penelitian ini bertujuan untuk mengetahui adanya Pseudomonas aeruginosa pada sampel pus infeksi luka operasi dari Rumah Sakit Umum Daerah Dr. Moewardi dan untuk mengetahui pola sensitivitasnya terhadap beberapa antibiotik.

Jenis penelitian ini adalah penelitian analitik observasional dengan pendekatan cross sectional. Bakteri Pseudomonas aeruginosa yang telah diisolasi dari sampel pada media Pseudomonas Selective Agar lalu dilakukan pengecatan Gram dan uji biokimia, kemudian dilakukan uji sensitivitas terhadap beberapa antibiotik yaitu: siprofloksasin, seftriakson, meropenem, sefotaksim, gentamisin, dan tobramisin dengan metode difusi Kirby Bauer. Hasil diameter zona hambat pada uji sensitivitas dibandingkan dengan standar diameter zona hambat menurut Clinical Laboratory Standard Institute.

Hasil penelitian menunjukkan bahwa dari 45 sampel pus infeksi luka operasi di Rumah Sakit Umum Daerah Dr. Moewardi teridentifikasi 11 sampel positif Pseudomonas aeruginosa. Hasil uji sensitivitas menunjukkan bahwa Pseudomonas aeruginosa sensitif 100\% terhadap meropenem. Hasil uji sensitivitas menunjukkan sensitif 90,90\% terhadap siprofloksasin, tobramisin dan gentamisin. Hasil uji sensitivitas menunjukkan sensitif63,63\% pada seftriakson dan hasil uji sensitivitas menunjukkan sensitif9,09\% pada sefotaksim.
\end{abstract}

Kata kunci: Pseudomonas aeruginosa, sensitivitas, antibiotik.

\section{ABSTRACT}

Wound infections are part of a nosocomial infection. One of the highest-cause bacterial infections of surgical wound is Pseudomonas aeruginosa. This study aims to determine the presence of Pseudomonas aeruginosa in a sample of pneumonia surgery wound surgery from the Regional General Hospital Dr. Moewardi and to know his sensitivity patterns against some antibiotics.

The type of this research is observational analytic research with cross sectional approach. Pseudomonas aeruginosa bacteria isolated from Pseudomonas Selective Agar samples were then performed Gram stain and biochemical test, and then tested sensitivity to some antibiotics: ciprofloxacin, ceftriaxone, meropenem, cefotaxime, gentamicin, and tobramycin by Kirby Bauer diffusion method. The result of inhibitory zone diameter on the sensitivity test was compared with standard inhibitory zone diameter according to Clinical Laboratory Standard Institute.

The results showed that of 45 samples of pussy wound infection surgery at the Regional General Hospital. Moewardi identified 11 positive samples of Pseudomonas aeruginosa. Sensitivity test results show that Pseudomonas aeruginosa is $100 \%$ sensitive to meropenem. Sensitivity test results showed $90.90 \%$ sensitivity to ciprofloxacin, tobramycin and gentamicin. Sensitivity test results showed a sensitivity of $63.63 \%$ in ceftriaxone and sensitivity test results showed a sensitivity of $9.09 \%$ in cefotaxime.

Keywords: Pseudomonas aeruginosa, sensitivity, antibiotics.

\section{PENDAHULUAN}

Infeksi luka operasi merupakan masalah yang serius, karena hal ini dapat berpengaruh pada kepentingan klinis dan gejala yang lebih serius, seperti meningkatnya angka kesakitan dan kematian pasien bedah, semakin bertambah 
lamanya masa perawatan dan meningkatkan biaya di rumah sakit (Sulistyaningrum, 2016). Menurut survei dari World Health Organization (WHO) menunjukkan sebesar 5\%-34\% dari total infeksi nosokomial berasal dari ILO (Haryanti et al, 2013). Angka kejadian ILO di Indonesia cukup tinggi, menurut DEPKES RI tahun 2011 angka kejadian ILO pada rumah sakit pemerintah di Indonesia sebanyak 55,1\% (Marsaoly, 2012). Bakteri Pseudomonas aeruginosa merupakan bakteri gram negatif penyebab tertinggi infeksi luka operasi. Pseudomonas aeruginosa tersebar luas di dunia dan terdapat pada tanah, air, udara (Misnadiarly dan Djajaningrat, 2014).

Masalah utama pada bakteri Pseudomonas aeruginosa saat ini adalah berkembangnya mikroorganisme ini yang resisten terhadap berbagai jenis antibiotika (Rustini et al., 2016). Berdasarkan hal tersebut perlu dilakukan monitoring berkala untuk mengetahui kerentanan bakteri Pseudomonas aeruginosa terhadap antibiotik, agar penggunaan antibiotik dalam pengobatan infeksi luka operasi yang disebabkan Pseudomonas aeruginosa dapat efektif. Penelitian ini bertujuan untuk mengetahui adanya bakteri Pseudomonas aeruginosa dari sampel pus infeksi luka operasi di RSUD Dr. Moewardi dan untuk mengetahui sensitivitasnya terhadap antibiotik meropenem, seftriakson, siproflokasasin, tobramisin, sefotaksim, gentamisin.

\section{METODE PENELITIAN}

Alat

Tabung reaksi steril, spuit, cawan petri, inkas, inkubator, autoclave, mikroskop, pinset, jarum ose, jarum ent, lampu spirtus, penggaris.

\section{Bahan}

Sampel pus infeksi luka operasi, media BHI, media PSA, media KIA, SIM, LIA, SCA, reagen Erlich A dan reagen Erlich B, xylol, minyak imersi, larutan kristal violet (Gram A), larutan lugol iodine (Gram B), larutan etanol 95\% aseton (Gram C), larutan safranin (Gram D).

\section{CARA KERJA}

\section{Isolasi Bakteri}

Sampel pus infeksi luka operasi digoreskan pada media PSA (Pseudomonas Selektive Agar) menggunakan kapas lidi dari media amies atau menggunakan jarum ose lalu diinkubasi pada inkubator selama $24-48$ jam pada suhu $37^{\circ} \mathrm{C}$. Hasil isolasi pada media PSA (Pseudomonas Selektive Agar) menunjukkan hasil positif adanya bakteri Pseudomonas aeruginosa jika terdapat pigmen piosianin atau pigmen pioverdin.

\section{Identifikasi Bakteri dengan Uji Biokimia Pengamatan Mikroskopis}

Prosedur pewarnaan Gram: (1) Koloni bakteri yang telah buat preparat ditetesi dengan kristal violet (Gram A), dibiarkan 60 detik dan dibilas dengan air mengalir, kemudian ditiriskan; (2) ditetesi dengan iodium (Gram B), dibiarkan 60 detik dan dibilas dengan air mengalir, kemudian ditiriskan; (3) preparat ditetesi larutan alkohol-aseton (Gram C) dibiarkan selama 15 sampai 30 detik dibilas dengan air mengalir, kemudian ditiriskan; (4) ditetesi safranin selama 60 detik kemudian dibilas dan dikeringkan; (5) preparat dilihat dibawah lensa mikroskop dengan perbesaran 1000x dengan penambahan minyak imersi.

\section{1) Uji Pada Media KIA}

Menginokulasikan koloni bakteri dari media PSA pada media KIA dengan menggunakan jarum ent secara aseptis dengan cara tusuk gores, lalu diinkubasi selama 24 jam pada suhu $37^{\circ} \mathrm{C}$ di inkubator.

\section{2) Uji Pada Media SIM}

Menginokulasikan koloni bakteri dari media PSA pada media SIM dengan menggunakan jarum ent secara aseptis secara tusuk, lalu diinkubasi selama 24 jam pada suhu $37^{\circ} \mathrm{C}$ di- 
inkubator.

3) Uji Pada Media LIA

Menginokulasikan koloni bakteri dari media PSA tersebut pada media LIA dengan menggunakan jarum ent secara aseptis secara tusuk gores, lalu diinkubasi selama 24 jam pada suhu $37^{\circ} \mathrm{C}$ di inkubator.

4) Uji Pada Media Citrat

Menginokulasikan koloni bakteri dari media PSA pada media Citrat

\section{Pembuatan suspensibakteri}

Isolat bakteri dari media PSA diinokulasikan pada media cair BHI (Brain Heart Infuction) kemudian diinkubasi selama 24 jam suhu $37^{\circ} \mathrm{C}$. Kekeruhan yang terjadi pada media BHI dibandingkan dengan standart Mc Farland $1,5 \times 10^{8} \mathrm{cfu} / \mathrm{ml}$.

\section{Uji Sensitivitas}

1) Medium Mueller Hinton Agar (MHA) yang telah dicairkan dituang ke dalam cawan petri steril diamkan hingga memadat, 2) Suspensi bakteri Pseudomonas aeruginosa pada media BHI yang telah dibandingkan

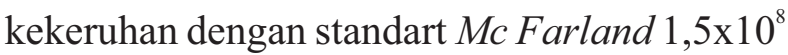
cfu/ml digoreskan dengan kapas lidi steril pada media MHA dengan metode perataan dan media didiamkan selama 10 menit pada suhu kamar, 3) Keenam kertas disk/cakram yang me- ngandung antibiotik diletakkan diatas media MHA yang telah ditanam bakteri dengan jarak yang sama, lalu diinkubasi pada inkubator selama 24 jam pada suhu $37^{\circ} \mathrm{C}$, 4) setelah itu diukur zona jernih yang terbentuk disekitaran cakram. Intrepetasi hasil mengacu pada CLSI (Clinical and Laboratory Standards Institute) dan digolongkan menjadi sensitif, intermediet, dan resisten.

\section{Hasil dan Pembahasan \\ Isolasi bakteri}

Hasil isolasi pada media PSA menunjukkan bahwa dari 45 sampel pus infeksi luka operasi terdapat 7 sampel yang membentuk pigmen piosianin dan 4 sampel yang mem-bentuk pigmen pioverdin. Pigmen piosianin (pigmen biru dan non fluoresen yang larut dalam air dan kloroform) dan pigmen pioverdin (berwarna kehijau-hijauan, berflouresensi, larut dalam air dan tidak larut dalam kloroform) dapat terbentuk disebabkan oleh adanya mag-nesium klorida dan kalium sulfat yang terkandung dalam media PSA (Anonim, 2011), seperti ditunjukkan di Gambar 1.

\section{Identifikasi Bakteri}

Mikroskopis

Pewarnaan Gram dari 11 sampel yang diduga positif menunjukkan bakteri Pseudomonas

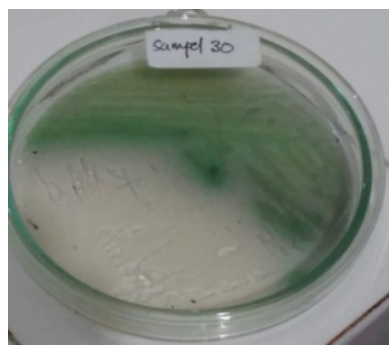

Gambar 1. Bakteri membentuk pigmen piosianin pada media PSA

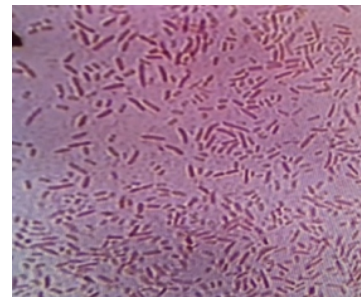

Gambar 2. Hasil pengecatan Gram bakteri Pseudomonas aeruginosa 
aeruginosa. Hal ini disebabkan karena bakteri Pseudomonas aeruginosa tergolong bakteri Gram negatif dimana pada pengecatan Gram akan menghasilkan warna merah, karena tidak menahan kompleks zat warna iodin dan menjadi transluen, bakteri ini dapat diwarnai lagi dengan safranin (zat berwarna merah) (Jawetz et al., 2012), seperti ditunjukkan di Gambar 2.

\section{Uji Biokimia}

Hasil uji KIA didapatkan hasil pada lereng dan dasar media berwarna merah serta tidak terbentuk warna hitam $\left(\mathrm{K} / \mathrm{K}^{\mathrm{S}-}\right)$. Bakteri Pseudomonas aeruginosa tidak membentuk asam karena bakteri yang tidak dapat memfermentasi glukosa dan laktosa, dan tidak membentuk warna hitam $\left(\mathrm{H}_{2} \mathrm{~S}\right.$ negatif) ( Harti, 2015).

Hasil uji SIM didapatkan hasil sulfida, indol negatif dan motilitas positif (--+). Hasil menunjukkan tidak terbentuk warna hitam $\left(\mathrm{H}_{2} \mathrm{~S}\right.$ negatif). Hasil dari uji indol menunjukkan negatif atau tidak terbentuk cincin merah setelah penambahan erlich A dan B (1:1). Hal ini disebabkan bakteri tidak membentuk indol dan triptophan sebagai sumber karbon.

Motilitas yang positif ditandai dengan adanya pertumbuhan dan penyebaran kekeruhan bakteri pada seluruh media.Hasil uji LIA didapatkan hasil menunjukkan warna ungu pada lereng dan dasar media serta tidak terbentuk warna hitam $\left(\mathrm{K} / \mathrm{K}^{\mathrm{S}-}\right)$. Berdasarkan hasil tersebut bakteri Pseudomonas aeruginosa tidak membentuk sulfida (warna hitam), tidak membentuk deaminasi lisin dan dapat membentuk dekarboksilasi lisin (warna ungu).
Hasil uji sitrat, hasil positif ditunjukkan dengan adanya pertumbuhan bakteri dan terjadinya perubahan warna media dari hijau menjadi biru yang disebabkan oleh peningkatan pH media di atas 7,6 karena adanya ammonia yang dihasilkan yang berasal dari monoammonium phosphate yang terdapat pada media (Sardiani et al., 2015). Berdasarkan hasil uji biokimia menunjukkan bahwa kesebelas sampel tersebut adalah Pseudomonas aeruginosa sesuai dengan sifat biokimianya.

Berdasarkan hasil koloni, pengecatan gram dan uji biokimia menunjukkan bahwa dari 45 sampel pus infeksi luka operasi di RSUD Dr. Moewardi teridentifikasi positif Pseudomonas aeruginosa sebanyak 11 sampel (24,44\%) ditunjukkan pada Tabel 1.

\section{Uji sensitivitas}

Hasil diameter zona hambat pada uji sensitivitas Pseudomonas aeruginosa terhadap antibiotik siprofloksasin $(5 \mu \mathrm{g})$, gentamisin $(10 \mu \mathrm{g})$, tobramisin $(10 \mu \mathrm{g})$, seftriakson $(30 \mu \mathrm{g})$, sefotaksim $(30 \mu \mathrm{g})$, meropenem $(10 \mu \mathrm{g})$ dibandingkan dengan standar diameter zona hambat menurut Clinical and Laboratory Standards Institute (CLSI).

Berdasarkan Gambar 4 menunjukkan bahwa 11 isolat Pseudomonas aeruginosa $100 \%$ sensitif terhadap antibiotik meropenem. Mekanisme kerja meropenem adalah mengganggu sintesis dinding sel bakteri, sehingga menghambat pertumbuhan bakteri dan menyebabkan kematian sel. Meropenem juga berpenetrasi dengan cepat ke dalam dinding sel bakteri dan berikatan dengan

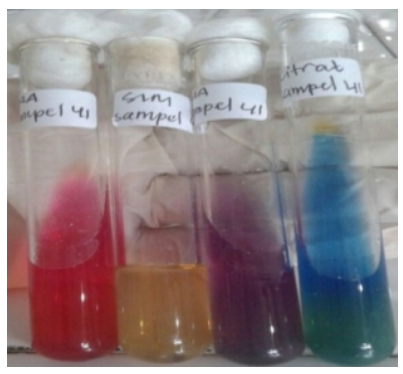

Gambar 3. Hasil uji biokimia Pseudomonas aeruginosa 
Tabel 1. Hasil Identifikasi Pseudomonas aeruginosa.

\begin{tabular}{|c|c|c|c|c|c|c|c|c|}
\hline \multirow[t]{2}{*}{ No } & \multirow{2}{*}{$\begin{array}{l}\text { No } \\
\text { sampel }\end{array}$} & \multirow{2}{*}{$\begin{array}{l}\text { Pigmen } \\
\text { koloni }\end{array}$} & \multirow[t]{2}{*}{ Mikroskopis } & \multicolumn{4}{|c|}{ Uji biokimia } & \multirow[t]{2}{*}{ Kesimpulan } \\
\hline & & & & KIA & SIM & LIA & Citrat & \\
\hline 1 & 4 & Piosianin & $\begin{array}{l}\text { bentuk batang, } \\
\text { warna merah }\end{array}$ & $\left(\mathrm{K} / \mathrm{K}^{\mathrm{S}-}\right)$ & $(--+)$ & $\left(\mathrm{K} / \mathrm{K}^{\mathrm{S}-}\right)$ & $(+)$ & $\begin{array}{l}\text { Pseudomonas } \\
\text { aeruginosa }\end{array}$ \\
\hline 2 & 7 & Piosianin & $\begin{array}{l}\text { bentuk batang, } \\
\text { warna merah }\end{array}$ & $\left(\mathrm{K} / \mathrm{K}^{\mathrm{S}}\right)$ & $(--+)$ & $\left(\mathrm{K} / \mathrm{K}^{\mathrm{S}-}\right)$ & $(+)$ & $\begin{array}{l}\text { Pseudomonas } \\
\text { aeruginosa }\end{array}$ \\
\hline 3 & 11 & Piosianin & $\begin{array}{l}\text { bentuk batang, } \\
\text { warna merah }\end{array}$ & $\left(\mathrm{K} / \mathrm{K}^{\mathrm{S}}\right)$ & $(--+)$ & $\left(\mathrm{K} / \mathrm{K}^{\mathrm{S}-}\right)$ & $(+)$ & $\begin{array}{l}\text { Pseudomonas } \\
\text { aeruginosa }\end{array}$ \\
\hline 4 & 17 & Pioverdin & $\begin{array}{l}\text { bentuk batang, } \\
\text { warna merah }\end{array}$ & $\left(\mathrm{K} / \mathrm{K}^{\mathrm{S}}\right)$ & $(--+)$ & $\left(\mathrm{K} / \mathrm{K}^{\mathrm{S}-}\right)$ & $(+)$ & $\begin{array}{l}\text { Pseudomonas } \\
\text { aeruginosa }\end{array}$ \\
\hline 5 & 18 & Piosianin & $\begin{array}{l}\text { bentuk batang, } \\
\text { warna merah }\end{array}$ & $\left(\mathrm{K} / \mathrm{K}^{\mathrm{S}}\right)$ & $(--+)$ & $\left(\mathrm{K} / \mathrm{K}^{\mathrm{S}-}\right)$ & $(+)$ & $\begin{array}{l}\text { Pseudomonas } \\
\text { aeruginosa }\end{array}$ \\
\hline 6 & 20 & Piosianin & $\begin{array}{l}\text { bentuk batang, } \\
\text { warna merah }\end{array}$ & $\left(\mathrm{K} / \mathrm{K}^{\mathrm{S}}\right)$ & $(--+)$ & $\left(\mathrm{K} / \mathrm{K}^{\mathrm{S}-}\right)$ & $(+)$ & $\begin{array}{l}\text { Pseudomonas } \\
\text { aeruginosa }\end{array}$ \\
\hline 7 & 25 & Pioverdin & $\begin{array}{l}\text { bentuk batang, } \\
\text { warna merah }\end{array}$ & $\left(\mathrm{K} / \mathrm{K}^{\mathrm{S}}\right)$ & $(--+)$ & $\left(\mathrm{K} / \mathrm{K}^{\mathrm{S}-}\right)$ & $(+)$ & $\begin{array}{l}\text { Pseudomonas } \\
\text { aeruginosa }\end{array}$ \\
\hline 8 & 28 & Pioverdin & $\begin{array}{l}\text { bentuk batang, } \\
\text { warna merah }\end{array}$ & $\left(\mathrm{K} / \mathrm{K}^{\mathrm{S}}\right)$ & $(--+)$ & $\left(\mathrm{K} / \mathrm{K}^{\mathrm{S}-}\right)$ & $(+)$ & $\begin{array}{l}\text { Pseudomonas } \\
\text { aeruginosa }\end{array}$ \\
\hline 9 & 30 & Piosianin & $\begin{array}{l}\text { bentuk batang, } \\
\text { warna merah }\end{array}$ & $\left(\mathrm{K} / \mathrm{K}^{\mathrm{S}}\right)$ & $(--+)$ & $\left(\mathrm{K} / \mathrm{K}^{\mathrm{S}-}\right)$ & $(+)$ & $\begin{array}{l}\text { Pseudomonas } \\
\text { aeruginosa }\end{array}$ \\
\hline 10 & 41 & Pioverdin & $\begin{array}{l}\text { bentuk batang, } \\
\text { warna merah }\end{array}$ & $\left(\mathrm{K} / \mathrm{K}^{\mathrm{S}}\right)$ & $(--+)$ & $\left(\mathrm{K} / \mathrm{K}^{\mathrm{S}-}\right)$ & $(+)$ & $\begin{array}{l}\text { Pseudomonas } \\
\text { aeruginosa }\end{array}$ \\
\hline 11 & 42 & Piosianin & $\begin{array}{l}\text { bentuk batang, } \\
\text { warna merah }\end{array}$ & $\left(\mathrm{K} / \mathrm{K}^{\mathrm{S}}\right)$ & $(--+)$ & $\left(\mathrm{K} / \mathrm{K}^{\mathrm{S}-}\right)$ & $(+)$ & $\begin{array}{l}\text { Pseudomonas } \\
\text { aeruginosa }\end{array}$ \\
\hline
\end{tabular}

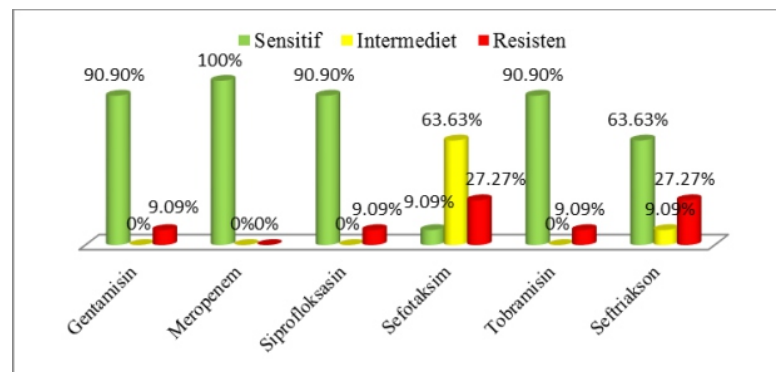

Gambar 4. Hasil prosentasi uji sensitivitas Pseudomonas aeruginosa terhadap antibiotik siprofloksasin, sefotaksim, gentamisin, meropenem, tobramisin seftriakson.

penicillin-binding-proteins (PBP) dengan afinitas yang tinggi, sehingga menginaktivasi bakteri (Halawiyah, 2015) .

Pseudomonas aeruginosa sensitif 90,90\% dan resisten $9,09 \%$ terhadap siprofloksasin. Mekanisme kerja antibiotik siprofloksasin adalah menghambat aktivitas DNA gyrase bakteri, bersifat bakterisid dengan spektrum luas terhadap bakteri Gram negatif maupun positif (Rieuwpassa et al., 2011). Hasil tersebut berbeda dengan penelitian dari Sulistyaningrum (2016) yang berjudul Pola kuman dan uji sensitivitasnya terhadap antibiotik pada penderita infeksi luka operasi (ILO) di RSUD Dr. Moewardi Periode januari - juli 2015 menunjukkan hasil bahwa Pseudomonas aeruginosa yang diisolasi dari sampel pus infeksi luka operasi resisten 100\% terhadap siprofloksasin.
Berdasarkan gambar 4 menunjukkan bahwa 11 isolat Pseudomonas aeruginosa 90,90\% sensitif dan resisten 9,09\% terhadap antibiotik gentamisin. Mekanisme kerja antibiotik gentamisin adalah menghambat sintesis protein. Membran terluar bakteri Gram negatif terdapat kanal protein dan gentamisin berdifusi masuk kedalam sel melalui kanal protein tersebut. Bakteri Gram negatif juga memiliki oxygen dependent system, merupakan sistem yang membawa obat memasuki membran sitoplasma. Setelah masuk ke dalam sitoplasma, gentamisin akan berikatan pada subunit 30S ribosom bakteri sehingga dapat mengganggu sintesis protein bakteri (Radji, 2015).

Berdasarkan hasil uji sensitivitas Pseudomonas aeruginosa terhadap tobramisin menunjukkan bakteri sensitif 90,90\% dan 
resisten 9,09\%. Mekanisme kerja antibiotik tobramisin adalah menghambat sintesis protein. Aktivitas superior tobramisin dalam melawan bakteri Pseudomonas aeruginosa menjadikan tobramisin sebagai golongan aminoglikosida yang dapat digunakan untuk pengobatan infeksi serius yang disebabkan oleh organisme ini (Goodman dan Gilman, 2006). Tobramisin sedikit lebih aktif terhadap Pseudomonas aeruginosa dibanding gentamisin (Jawetz et al., 2012).

Hasil uji sensitivitas bakteri Pseudomonas aeruginosa terhadap antibiotik seftriakson menunjukkan hasil $63,63 \%$ sensitif, 9,09\% intermediet, dan 27,27\% resisten. Mekanisme kerja seftriakson adalah dengan cara menghambat sintesis dinding sel mikroba, enzim transpeptidase dihambat pada pembentukan dinding sel (Marsono, 2015). Hasil penelitian ini berbeda dengan hasil penelitian dari Sulistyaningrum (2016) yang berjudul Pola kuman dan uji sensitivitasnya terhadap antibiotik pada penderita infeksi luka operasi (ILO) di RSUD Dr. Moewardi Periode januari - juli 2015 menunjukkan bahwa Pseudomonas aeruginosa resisten 100\% terhadap seftriakson. Menurut pedoman penggunaan antibiotik profilaksis di RSUD Dr. Moewardi tahun 20112012, seftriakson merupakan antibiotik yang paling banyak digunakan pada penderita infeksi luka operasi (Sulistyaningrum, 2016).

Hasil uji sensitivitas Pseudomonas aeruginosa terhadap antibiotik sefotaksim $9,09 \%$ sensitif, intermediet $63,63 \%$, dan $27,27 \%$ resisten. Hasil penelitian hasil uji sensitivitas Pseudomonas aeruginosa dominan intermediet yaitu sebesar 63,63\%. Intermediet adalah suatu pola kepekaan strain bakteri terhadap antibiotik yang bersifat saat dihambat secara in vitro oleh konsentrasi obat yang standar dikaitkan dengan efek terapeutik yang tidak pasti (Rodloff et al., 2008). Dosis antibiotik yang standar diberikan kedalam tubuh, tidak dapat menghambat pertumbuhan bakteri sehingga perlu dilakukan perubahan dosis antibiotik agar bakteri dapat terhambat pertumbuhannya. Namun dengan perubahan dosis obat yang lebih tinggi perlu diperhatikan bagaimana efek toksik terhadap tubuh.

\section{Kesimpulan}

1. Terdapat bakteri Pseudomonas aeruginosa sebesar 24,44\% (11 sampel) dari sampel pus infeksi luka operasidi RSUD Dr. Moewardi.

2. Sensitivitas bakteri Pseudomonas aeruginosa terhadap meropenem adalah 100\% sensitif. Sensitivitas bakteri Pseudomonas aeruginosa terhadap siprofloksasin, tobramisin dan gentamisin adalah 90,90\% sensitif. Sensitivitas bakteri Pseudomonas aeruginosa terhadap seftriakson dan sefotaksim masing masing menunjukkan sensitif sebesar 63,63\%, dan $9,09 \%$.

\section{Saran}

1. Perlu dilakukan penelitian terhadap bakteri patogen lainnya yang terdapat pada sampel pus infeksi luka operasi.

2. Antibiotik meropenem, gentamisin, tobramisin, siprofloksasin, seftriakson dapat direkomendasikan untuk pengobatan infeksi luka operasi akibat bakteri Pseudomonas aeruginosa.

3. Perlu dilakukan monitoring secara berkala untuk melihat pola kepekaan bakteri terhadap antibiotik.

\section{DAFTAR PUSTAKA}

Anonim. 2011. Cetrimide Agar. Mumbay: HiMedia Laboratories.[online]http://himedialabs.com/TD/M024.pdf/.

Goodman, L., Gilman, A. 2006. The Pharmacological Basis of Therapeutics.Eleventh Edition. United States of America: The McGraw-Hill Companies, Inc.

Halawiyah, A. 2015. Evaluasi Kualitatif Penggunaan Antibiotik Meropenem Pada Pasien Sepsis BPJS Di Rumkital DR. Mintohardjo Tahun 2014 [skripsi]. Jakarta: Fakultas Kedokteran dan Ilmu Kesehatan, Program Studi Farmasi, UIN Syarif Hidayatullah.

Harti, A.S. 2015. Mikrobiologi Kesehatan: Peran Mikrobiologi Dalam Bidang Kesehatan. Yogyakarta: Andi Offset.

Haryanti, L., Pudjiadi, AH., Ifran EKB., Thayeb, A., Amir, I., Hegar, B. 2013. Prevalens dan Faktor Risiko Infeksi Luka Operasi Pasca-bedah. Sari Pediatri, Vol. 15(4):207-212. 
Jawetz.,Melnick.,Adelberg. 2012. Mikrobiologi Kedokteran. Edisi 25. The McGraw-Hill Education amd EGC Medical Publisher, alih bahasa Widhi A, [et al], Adityaputri A, [et al], editor. Jakarta: Buku Penerbit Kedokteran (EGC). Terjemahan dari: Medical Mikrobiology.

Misnadiarly, AS.APU., Djajaningrat, H. 2014. Mikrobiologi Untuk Klinik dan Laboratorium. Jakarta: Rineka Cipta.

Marsaoly, S.F.A. 2016. Infeksi Luka Post Operasi Pada Pasien Post Operasi Di Bangsal Bedah RS PKU Muhammadiyah Bantul [skripsi]. Yogyakarta:Fakultas Kedokteran dan Ilmu Kesehatan, Universitas Muhammadiyah Yogyakarta.

Marsono, Y. 2015. Evaluasi Penggunaan Antibiotik pada Pasien Pnemumonia dengan Metode Gyssens di Instalasi Rawat Inap Rumah Sakit Dr. Moewardi Surakarta Tahun 2013 [skripsi]. Surakarta: Fakultas Farmasi, Universitas Muhammadyah Surakarta.

Radji, M. 2015. Mekanisme Aksi Molekuler: Antibiotik dan Kemoterapi. Jakarta: Penerbit Buku Kedokteran EGC.

Rieuwpassa, I.E., Yunus, M., Arsana, I.W.S. 2011. Identifikasi Pseudomonas aeruginosa dan tes sensitivitas siprofloksasin pada abses periodontal. Dentofasial, Vol.10(3):151-155.
Rodloff A., Bauer T., Ewig S., Kujath P., Müller E. 2008. Susceptible, Intermediate, and Resistant-The Intensity of Antibiotic Action.Deutsches Ärzteblatt International.Dtsch Arztebl Int, 105(39):657-62.

Rustini.,Istiqamah, S., Armin, F. 2016. Penentuan Multi Drug Resisten Pseudomonas aeruginosa (Mdrpa) yang Berasal dari Sampel Klinis Pasien Rsup Dr. M. Djamil Padang. Prosiding Rakernas dan Pertemuan Ilmiah Tahunan Ikatan Apoteker Indonesia 2016. Padang : Fakultas Farmasi, Universitas Andalas.

Sardiani, N., Litaay, M., Budji, R.G., Priosambodo D., Syahribulan., Dwyana Z. 2015. Potensi Tunikata Rhopalaea Sp Sebagai Sumber Inokulum Bakteri Endosimbion Penghasil Antibakteri; 1. Karakterisasi Isolat. Makassar: FMIPA Universitas Hasanuddin. Jurnal Alam dan Lingkungan Vol.6 No.11

Sulistyaningrum, N.F. 2016. Pola Kuman Dan Uji Sensitivitasnya Terhadap Antibiotik Pada Penderita Infeksi Luka Operasi (ILO) Di RSUD Dr Moewardi Periode Januari-Juli 2015 [skripsi]. Surakarta: Fakultas Farmasi, Universitas Muhammadyah Surakarta. 